\title{
Observed and Future Changes in the Temperature of the State of Jalisco, México Using Climdex and PRECIS
}

\author{
H. U. Ramírez-Sánchez, M. E. García Guadalupe, H. H. Ulloa-Godínez, A. R. Meulenert-Peña, \\ F. O. García-Concepción, J. Alcalá Gutiérrez \\ Institute of astronomy and meteorology, University Center of Exact Sciences and Engineering, University of \\ Guadalajara, Guadalajara, Mexico \\ Email:ramirez@astro.iam.udg.mx
}

Received 8 December 2015; accepted 15 March 2016; published 18 March 2016

Copyright (C) 2016 by authors and Scientific Research Publishing Inc.

This work is licensed under the Creative Commons Attribution International License (CC BY). http://creativecommons.org/licenses/by/4.0/

(c) (i) Open Access

\begin{abstract}
In the present study we analyzed the average and extreme temperatures observed and simulated by regional models in the State of Jalisco, Mexico. Data of daily mean, minimum and maximum temperatures of 208 stations distributed all over the State during the period 1971-2000 have been used to study the observed changes in the values of average and extreme temperatures. In addition, an assessment of future scenarios for the average and extreme temperatures associated with the increase in the concentration of greenhouse gases (GHG) was performed using simulations of a PRECIS (Providing Regional Climate for Impact Studies) regional climate modeling to create the climate for present (1971-2000), and future projections for the years 2020, 2050 and 2080. 0 bservational analysis of the 208 stations suggests warming through increased intensity and frequency of hot events, with a decrease in the frequency of cold events. More than $35 \%$ to $76 \%$ of the stations have a tendency to a decrease in the number of cold events and $39 \%$ to $64 \%$ of the stations show a growing trend in the hot events. The percentage of stations showing warming through the indices of intensity of the highest maximums, lowest minimum temperatures is $\mathbf{3 7 \%}$ to $70 \%$ and $30 \%$ to $65 \%$ of the stations, respectively. Observational analysis for the State of Jalisco as a whole also shows similar results. Anomalies in the average and extreme temperatures per month during the data period show an increase (decrease) in the frequency of hot (cold) events for every month. In general, PRECIS simulations under both scenarios A1B and A2 indicate an increase in warm events and decrease of cold extreme events towards the end of the 21st century. Both show similar patterns, but the scenario A2 shows slightly lower magnitudes of projected changes. Temperatures are likely to increase all year, but it is expected that changes in summer will be more prominent.
\end{abstract}

How to cite this paper: Ramírez-Sánchez, H.U., García Guadalupe, M.E., Ulloa-Godínez, H.H., Meulenert-Peña, A.R., GarcíaConcepción, F.O. and Alcalá Gutiérrez, J. (2016) Observed and Future Changes in the Temperature of the State of Jalisco, México Using Climdex and PRECIS. American Journal of Climate Change, 5, 38-51.

http://dx.doi.org/10.4236/ajcc.2016.51006 


\section{Keywords}

\section{Average and Extreme Temperatures, Scenarios, Diurnal Temperature Range}

\section{Introduction}

Since the industrial revolution, there has been a marked increase in the emission of greenhouse gases, mainly $\mathrm{CO}_{2}$ and $\mathrm{CH}_{4}$ in the atmosphere, raising atmospheric temperatures of the Earth's surface. The fourth assessment report of the Intergovernmental Panel on Climate Change [1] concluded that average surface temperatures have increased $0.74^{\circ} \mathrm{C} \pm 0.18^{\circ} \mathrm{C}$ following a linear trend in the past 100 years (1906-2005). The rate of warming in the past 50 years is nearly twice that in the past 100 years [1], largely attributed to anthropogenic influences. However the fifth assessment report of the Intergovernmental Panel on Climate Change [2] estimated a warming of $0.85^{\circ} \mathrm{C} \pm 0.20^{\circ} \mathrm{C}$, during the period $1880-2012$, which has occurred independently verified using several sets of data. In the case of Mexico, the average, maximum and minimum temperatures have increased by about $0.2^{\circ} \mathrm{C}$ per decade during the period 1971-2003, for the country as a whole [3]. Regional studies on changes in temperature for China [4], Japan [5], Korean Peninsula [6], the Mediterranean region [7] [8], and Europe [9] show consistent patterns with a general warming. The last decade of the last century and the first of this century have been the warmest years ever recorded; the phenomenon has been global in nature, although warming trends do not show a great spatial and temporal variability.

Until recently, most of the studies on long-term global climate change through temperature records have focused on changes in mean values. The temperature is an integral component of climate variability and change on the regional scale. The extremes in temperatures are characterised by tolerance level exceeding daily temperature and their frequencies are of great interest in terms of human impact. They have important socio-economic implications, such as its direct impact on the performance of the farming, power generation and consumption, and the human health among other factors [10]-[13]. There are many regional studies on the basis of recorded data and only a few results of the model simulations.

In China, there has been a slight decline in 1 day of extreme maximum temperature during each season, except for the spring, but the extreme minimum temperature has shown a strong upward trend in each season [14]. In Northern and central Europe, there is an evidence of a decrease in the number of frosty days since 1930 [15], which appears to be associated with a sharp increase in minimum temperatures of winter. Symmetrical heating of warm and cold tails of the distribution of the daily minimum and maximum temperature during 1946-1999 has been evidenced in Europe [16]. It has been shown that for southern hemisphere countries such as Australia and New Zealand, the frequency of frozen days increased with the rise of the daily minimum temperature from 1961 [17]. Recent researches on the period 1960-2000 in indices of daily temperature over South America have indicated a significant trend towards increase in the percentage of warm nights and downward trends in the percentage of cold nights at many stations [18]. Many other regional studies have addressed the analysis of frequencies of warm and cold events and have indicated that the cold extremes are diminishing and the warm extremes are increasing [10] [19]-[23]. In the fifth report of the IPCC [2], it was concluded that changes in extreme temperatures are consistent with the observed warming of the climate.

More reliable regional climate change projections are now available for many regions of the world due to advances in modeling and understanding of the physical processes of the climate system. However, constraints arise due to uncertainties in factors such as change of population, economic variables, technological developments and other relevant characteristics of future human activity, which constitute important ingredients of climate simulation models. Therefore, certain carefully considered scenarios are developed to project global climate scenarios predicted for the future and their possible consequences. Houghton et al. [24] have concluded that the projections of the statistical aspects of weather phenomena and climate extremes can be derived from climate models that represent possible future climate states. The third assessment report (TAR) of the IPCC has incorporated future climate change and extreme weather events in these models [25]. Many studies have deduced that most of the increase in the global average observed during the second half of the 20th century, can be attributed to anthropogenic forcing [25]-[30]. Changes in the general warming and rainfall over the State of Jalisco indicate, using atmosphere-ocean-coupled general circulation models, an increase of the greenhouse effect 
scenarios. There have been agreements made at global/regional scales to also determine the nature of the changes in the extremes in other regions of the world [22] [31]-[34]; however, a clear picture of such changes with regional details have not been made in this region of Mexico.

In this study an attempt is made to investigate current changes and projections to the end of the 21st century for the State of Jalisco, México, using temperature models.

\section{Material and Methods}

The data for average, maximum and minimum temperatures for the period 1971-2000 and 1981-2010 were obtained from the National Meteorological Service (SMN) belonging to the National Water Commission (CNA), attached to the Ministry of Environment and Natural Resources (SEMARNAT) of a network of 208 meteorological stations distributed in the State of Jalisco (Figure 1). Prior to the processing we carried out an assessment of the data quality as a prerequisite for the calculation of the indices, since any atypical or wrong value could have serious repercussions on the analysis of trends. Therefore, some basic procedures of data processing were performed to examine the data of the individual stations. This allowed the identification of some extreme outliers and also helped in the identification of possible inhomogeneity and lack of values in the data sets. Metadata files are configured for each station to identify doubtful values and track changes in the data sets. All suspicious daily temperature values were identified by the different quality controls; for example, the maximum temperature below the minimum temperature, daily values more than four standard deviations from the average for the time of year and also by visual inspection of the historical record. Suspicious records are identified using various data sources, and the erroneous values are replaced by the correct values. The stations used in the study are selected based on the quality of the data, the duration of data availability and homogeneity to comply with these requirements. Only 197 of the 208 analyzed stations were finally used [35] [36]. The simulations using

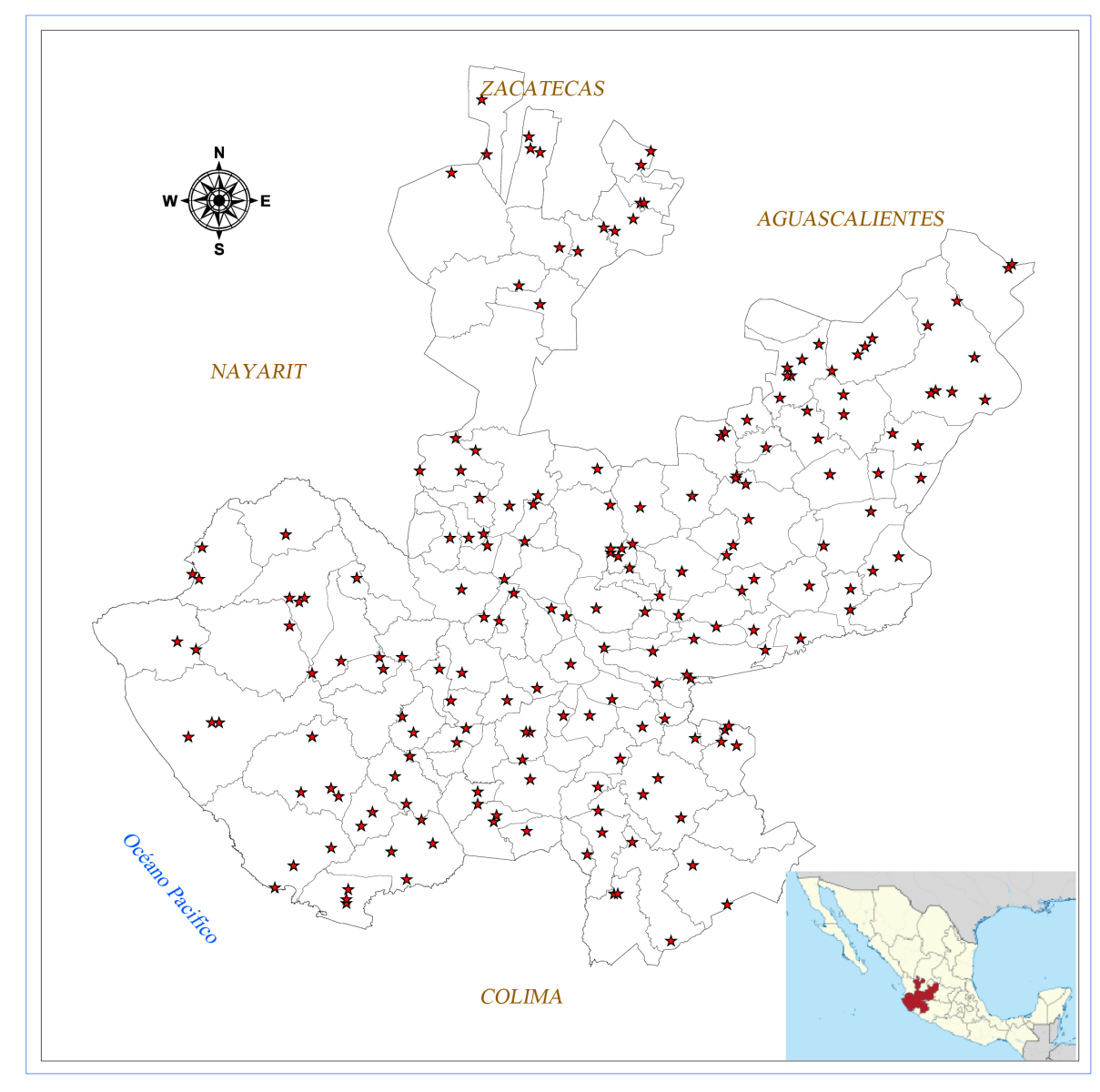

Figure 1. Geographical location of the 208 weather stations considered in this study. 
PRECIS have been performed to generate the past climate (1971-2000) and for the future periods of 2020, 2050 and 2080 for two different socio-economic scenarios, both characterized by a focused regional development but with priority to economic issues in the first (scenario A2) and environmental issues in the second (scenario A1B). A detailed description of these scenarios is available in IPCC special report on emissions scenarios SRES, [37]. PRECIS is configured for a domain which extends from approximately $-101^{\circ} 28^{\prime} \mathrm{W}$ to $-105^{\circ} 42^{\prime} \mathrm{W}$ longitude and $18^{\circ} 55^{\prime} \mathrm{N}$ to $22^{\circ} 45^{\prime} \mathrm{N}$ latitude with $0.22^{\circ} \times 0.22^{\circ}$ of horizontal resolution. A complete description of PRECIS is provided by Jones et al. [38]. In this study, the characteristics of the mean and extreme temperatures are investigated to predict their future scenarios using data average, daily minimum and maximum temperatures of PRECIS for baseline (1961-1990) and the A1B and A2 scenarios 2020, 2050 and 2080.

An important issue that arises in assessing changes in extremes is how to objectively define and quantify the various types of extremes in the weather elements. The Commission of the World Meteorological Organization (WMO) for the team of experts in climatology concerning climate change detection, monitoring and indices (ET-CCDMI) has been coordinating efforts to develop a set of relevant indices and make possible their global analysis through regional participation. In this study, some of the indices developed by the ETCCDMI (Table 1) are calculated using RClimdex software at each station to assess trends and also evaluations were made using simulations with PRECIS during the same period.

The maximum and minimum temperature data from PRECIS using baseline (1971-2000) data are used to evaluate the ability of the model in the representation of the regional climatic characteristics of the temperature extremes on the basis of comparisons with in-situ observations for the State of Jalisco. To eliminate possible apparent biases due to the differences in density space between observation and model data representations, as well as the methodology, the data from the model have been downgraded in resolution to match it with the observation network. The daily mean, maximum and minimum temperatures from PRECIS data are extracted for the coordinates of each respective station for which real observational data are available. In addition, similar approaches in diagnostic analysis have been applied to both models, as well as the sets of observed data.

For the comprehensive analysis, the spatially aggregated monthly average indices for the State of Jalisco are calculated using the simple arithmetic mean of the respective indices of all stations analyzed to see changes in the annual cycle. Trends were calculated for each station and for the whole of Jalisco State on time series for all indices of average and extreme temperatures. Extreme indices usually do not follow a Gaussian distribution, and therefore a simple linear least-squares trend estimate would not be appropriate. Therefore, slope Mann-Kendall non-parametric estimators based on the statistical range are used to test the significance of the long-term trends

Table 1. List of extreme temperature indices used.

\begin{tabular}{|c|c|c|c|}
\hline & Index & Description & Definition \\
\hline \multirow{4}{*}{ 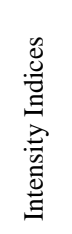 } & $\mathrm{TXX}$ & Hottest day & Highest maximum temperature in a year \\
\hline & TXn & Coldest day & Lowest maximum temperature in a year \\
\hline & $\mathrm{TNx}$ & Hottest night & Highest minimum temperature in a year \\
\hline & TNn & Coldest night & Lowest minimum temperature in a year \\
\hline \multirow{4}{*}{ 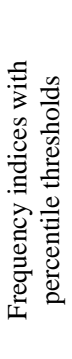 } & TX90p & Hot days & $\begin{array}{l}\text { Percentage of days in a year with maximum temperature above 90th percentile } \\
\text { of daily maximum temperature distribution in the 1971-2000 baseline period }\end{array}$ \\
\hline & TN90p & Hot nights & $\begin{array}{l}\text { Percentage of days in a year with minimum temperature above 90th percentile } \\
\text { of daily minimum temperature distribution in the } 1971-2000 \text { baseline period }\end{array}$ \\
\hline & TX10p & Cold days & $\begin{array}{l}\text { Percentage of days in a year with maximum temperature below 10th percentile } \\
\text { of daily maximum temperature distribution in the } 1971-2000 \text { baseline period }\end{array}$ \\
\hline & TN10p & Cold nights & $\begin{array}{l}\text { Percentage of days in a year with minimum temperature below } 10 \text { th percentile } \\
\text { of daily minimum temperature distribution in the } 1971-2000 \text { baseline period }\end{array}$ \\
\hline 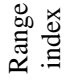 & DTR & $\begin{array}{l}\text { Diurnal temperature } \\
\text { range }\end{array}$ & $\begin{array}{l}\text { Annual mean of difference between maximum temperature and } \\
\text { minimum temperature }\end{array}$ \\
\hline
\end{tabular}


in the time series [39]. These tests are widely used in environmental science, because they are simple and do not assume a distribution of residuals, to limit the effect of extreme values of the series, and they can cope with the missing values below detection limits.

\section{Results and Discussion}

Observational analysis in the whole State of Jalisco and the seasonal and annual mean surface air temperature of the region was carried out in the year 2015 by Ramirez et al. [3]. They showed an increase of $0.17^{\circ} \mathrm{C}$ over 60 years using the network of 197 stations, providing the first quantitative indications that the State of Jalisco shares aspects with large scale global warming. The decadal average temperatures trend analysis also provided a similar result. Although some studies have tried to perform an analysis of the climate change observed over the Western Mexico region, including the analysis of the extremes, there is still a lack of systematic and comprehensive analysis of the changes in the extremes. Therefore, we have attempted to analyze the extremes observed in the air surface temperature in terms of their intensity and frequency using daily data from the stations of the State of Jalisco.

Temperatures are well known to have large seasonal variations, which are also reflected in the annual cycles of extreme events of temperature [40]. It is of great interest to examine possible changes in annual cycles, to see if there is a detectable change in annual climatological patterns of occurrence of extreme events of temperature on the scale of the State of Jalisco. A simple way of determining if there have been notable changes in annual cycles is to examine the annual cycles of averages into two equal halves of the data period, using the semiaverage method of the estimation of change. To this end, the annual cycle in terms of all monthly average indices for both halves of the period consisting of 30 years each has been analyzed. Changes in the State of Jalisco refer to the comparison of indices over two periods, namely, 1971-2000 and 1981-2010, and these differences have been calculated for each month.

Indices of average monthly intensity of extreme events of temperature 1) the lowest minimum temperature of the year (TNn), 2) the highest minimum temperature of the year (TNx), 3) the lowest maximum temperature of the year (TXn) and 4) the highest maximum temperature of the year (TXx) in the two sub-periods are presented in Table 2. Changes in the averages between time periods give an idea of the intensity $\left({ }^{\circ} \mathrm{C}\right)$ incremental behavior. Annual cycles for both periods show very different patterns for each index of intensity (Table 1), which indicates that there are major changes in the basic characteristics of the seasonal cycle. However, incremental changes in both seasons show the temperature increasing yearly in almost all levels of intensity, in every month. But, the magnitudes of the rises in temperature vary from month to month and also vary from one index to another. The magnitudes of the changes are relatively less $\left(0.40^{\circ} \mathrm{C}-2.4^{\circ} \mathrm{C}\right)$ during the precipitation months (June-October), and the temperature rise is relatively high $\left(-0.40^{\circ} \mathrm{C} \pm 3.47^{\circ} \mathrm{C}\right.$ to $\left.-2.4^{\circ} \mathrm{C} \pm 3.63^{\circ} \mathrm{C}\right)$ in the dry

Table 2. Intensity indices for monthly average extreme events of temperature for the State of Jalisco obtained through RClimdex.

\begin{tabular}{|c|c|c|c|c|c|c|c|c|}
\hline \multirow[b]{2}{*}{ Changes } & \multicolumn{2}{|c|}{$\begin{array}{l}\text { TNn the lowest } \\
\text { minimum temperature } \\
\text { of the year }\end{array}$} & \multicolumn{2}{|c|}{$\begin{array}{l}\text { TNx the highest minimum } \\
\text { temperature of the year }\end{array}$} & \multicolumn{2}{|c|}{$\begin{array}{l}\text { TXn the lowest } \\
\text { maximum } \\
\text { temperature of the year }\end{array}$} & \multicolumn{2}{|c|}{$\begin{array}{l}\text { TXx the highest maximum } \\
\text { temperature of the year }\end{array}$} \\
\hline & $71-00$ & $81-10$ & $71-00$ & $81-10$ & $71-00$ & $81-10$ & $71-00$ & $81-10$ \\
\hline Positives & 104 & 55 & 92 & 64 & 125 & 117 & 148 & 98 \\
\hline Negatives & 128 & 98 & 144 & 89 & 108 & 36 & 86 & 55 \\
\hline Total & 232 & 153 & 236 & 153 & 233 & 153 & 234 & 153 \\
\hline Average & -0.40 & -0.87 & -0.62 & -0.19 & 0.25 & 2.40 & 0.65 & 1.23 \\
\hline Std. dev. & 3.47 & 2.69 & 2.21 & 1.96 & 3.54 & 3.63 & 3.64 & 2.79 \\
\hline Max & 14.80 & 5.86 & 5.00 & 4.00 & 11.00 & 12.31 & 9.00 & 7.31 \\
\hline Min & -13.00 & -5.76 & -8.00 & -6.39 & -10.00 & -5.77 & -28.00 & -2.60 \\
\hline \% Positives & 44.83 & 35.95 & 38.98 & 41.83 & 53.65 & 76.47 & 63.25 & 64.05 \\
\hline \% Negatives & 55.17 & 64.05 & 61.02 & 58.17 & 46.35 & 23.53 & 36.75 & 35.95 \\
\hline
\end{tabular}


period (November-May). In addition, changes in the temperature of the coldest day (TXn) are generally higher than for the other levels of intensity.

The differences in the annual cycles of the indices of frequency of events based on 10 and 90 percentile value of hot and cold threshold, namely 1) cold nights (TN10p), 2) hot nights (TN90p), 3) cold days (TX10p) and 4) hot days (TX90p), for both periods are presented in Table 3. Both the number of hot days and hot nights (TX90P and TN90p) show the frequencies increase in almost every month, while the cold days and cold nights (TX10p and TN10p) show a decrease in frequency in all the months of the year. In a similar trend to the intensity indices, the frequency indices also show relatively small changes during the months of the rainy season and relatively greater changes in the dry season. A statistical t-Student test has been used to determine the significance of the changes in the average. Changes in indices between the two periods are statistically significant except for the cold days, which show the same trend.

\subsection{Trends at the Level of Stations}

The Mann-Kendall trend estimates were calculated for indices of both temperature maximum and minimum in each of the 197 study stations and also to the spatially added regional time series for the State of Jalisco as a whole. All trend values were required to have a statistical significance at the $5 \%$ level. Trends of the extreme levels of the annual temperature of the stations are summarized in Table 2 and Table 3 . All levels of intensity of both hot and cold events (cold days and cold night-time temperatures; and hot days and hot night-time temperatures; TXn, TNN, TXx, TNN) showed a general upward trend. All the hot events (TX90p and TN90p) frequency indices also show a general increasing trend, and all levels of frequency of cold events (TX10p and TN10p) show a general downward trend. Many stations show changes towards warming by increasing trends of high maximum temperature (from 37\% to $70 \%$ ), less events of minimum temperature (from $35 \%$ to $76 \%$ ), the number of hot days (from $47 \%$ to $79 \%$ ) and hot nights (from $37 \%$ to $67 \%$ ), while there is a decrease in the number of cold days (46\% to 29\%) and cold nights (from 64\% to 33\%) in the periods, 1971-2000 and 1981-2010, respectively. Opposite trends towards cooling are seen in some stations.

Many stations show changes towards warming. In this section, we examine their spatial characteristics. The spatial patterns of the trends in indices of intensity in the period 1970-2003 are presented in Figure 2. The highest maximum temperature (TXx) and the lowest minimum temperature (TNN) show increasing trends in large parts of the State. Trends in the rest of the intensity indices (lowest maximum temperature, TXn and highest minimum temperature, TNx) have less spatial coherence. However, most of the significant increasing trends are more to the North and to the West (coastal zone). The decreases of the observed trends in a few of the stations, are mostly insignificant for all levels of intensity.

General warming trends are seen from the frequency indices also. The frequency of cold events (TN10p and TX10p) show downward trends, while the frequency of hot events indicates a growing trend (TX90p and TN90p) (Table 1 and Table 2). However, the decrease of the trends in the frequency of cold events (TX10p and TN10p)

Table 3. Frequency indices of warm and cold events to the 10 and 90 percentile value threshold for the State of Jalisco obtained through R-Climdex.

\begin{tabular}{|c|c|c|c|c|c|c|c|c|}
\hline \multirow[b]{2}{*}{ Changes } & \multicolumn{2}{|c|}{ TN10P cold nights } & \multicolumn{2}{|c|}{ TN90P hot nights } & \multicolumn{2}{|c|}{ TX10P cold days } & \multicolumn{2}{|c|}{ TX90P hot days } \\
\hline & $71-00$ & $81-10$ & $71-00$ & $81-10$ & $71-00$ & $81-10$ & $71-00$ & $81-10$ \\
\hline Positives & 43 & 9 & 25 & 18 & 30 & 8 & 31 & 19 \\
\hline Negatives & 24 & 18 & 42 & 9 & 34 & 19 & 34 & 8 \\
\hline Total & 67 & 27 & 67 & 27 & 64 & 27 & 65 & 27 \\
\hline Average & 4.40 & 2.13 & -5.30 & 3.82 & -3.02 & -2.98 & -0.75 & 7.01 \\
\hline Std. Dev. & 14.39 & 12.67 & 15.66 & 7.71 & 14.68 & 9.50 & 20.60 & 12.59 \\
\hline Max & 40.00 & 35.77 & 42.00 & 15.36 & 38.00 & 22.09 & 45.00 & 22.46 \\
\hline Min & -45.00 & -7.40 & -38.00 & -9.07 & -38.00 & -24.60 & -39.00 & -12.17 \\
\hline \% Positives & 64.18 & 33.33 & 37.31 & 66.67 & 46.88 & 29.63 & 47.69 & 70.37 \\
\hline \% Negatives & 35.82 & 66.67 & 62.69 & 33.33 & 53.13 & 70.37 & 52.31 & 29.63 \\
\hline
\end{tabular}


have large spatial extent throughout the State. Increasing trends in hot events (TX90p and TN90p) have less spatial coherence. Similar to the intensity indices, the majority of the most significant trends are to the North and West of the State.

It is important that any data of simulated models should be used only after a prior assessment of the ability and the reliability of the model based on comparisons with in-situ observations. Therefore, evaluation of the model is considered to be one of the most important steps in studies based on data from the simulated model. Regional high-resolution simulations generated using PRECIS have been studied in detail by Ramírez et al. [3] to determine the reliability of the model in the representation of the regional climatic characteristics. Simulations of air surface temperature in the State of Jalisco have been examined. However, the main objective of the evaluation was to examine PRECIS in its simulating of the climate in the State of Jalisco. Therefore, Ramírez et al. [3] have examined the evaluation of daily maximum and minimum temperature extremes in the State of Jalisco in detail and concluded that PRECIS is capable of capturing climate of State of Jalisco with an uncertainty of $\pm 1.7^{\circ} \mathrm{C}$ (Figure 3 \& Figure 4).

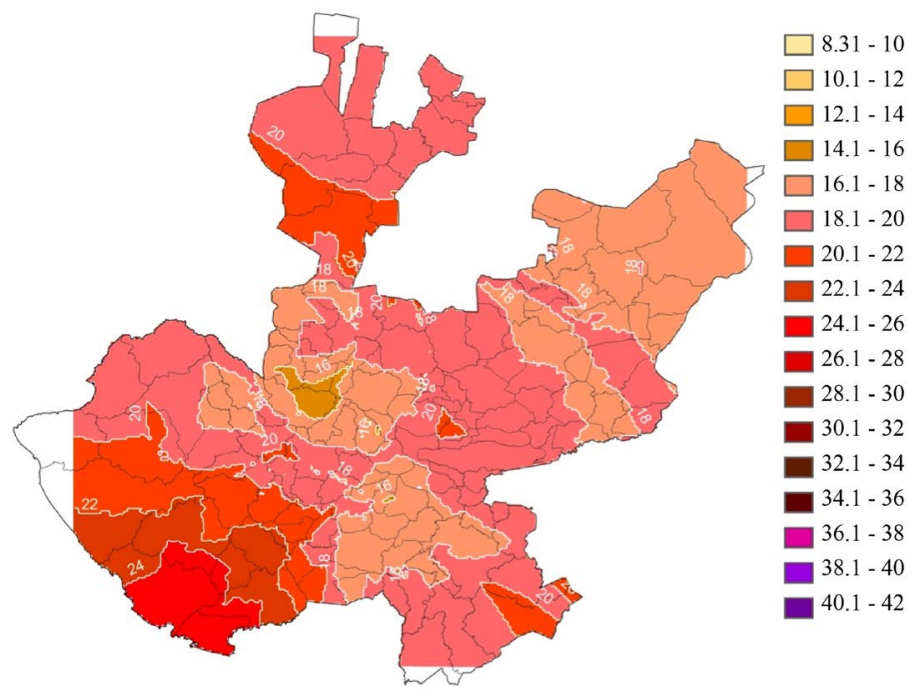

Figure 2. Spatial patterns of the trends in the indices of temperature intensity in the period 1970-2003 for the State of Jalisco.
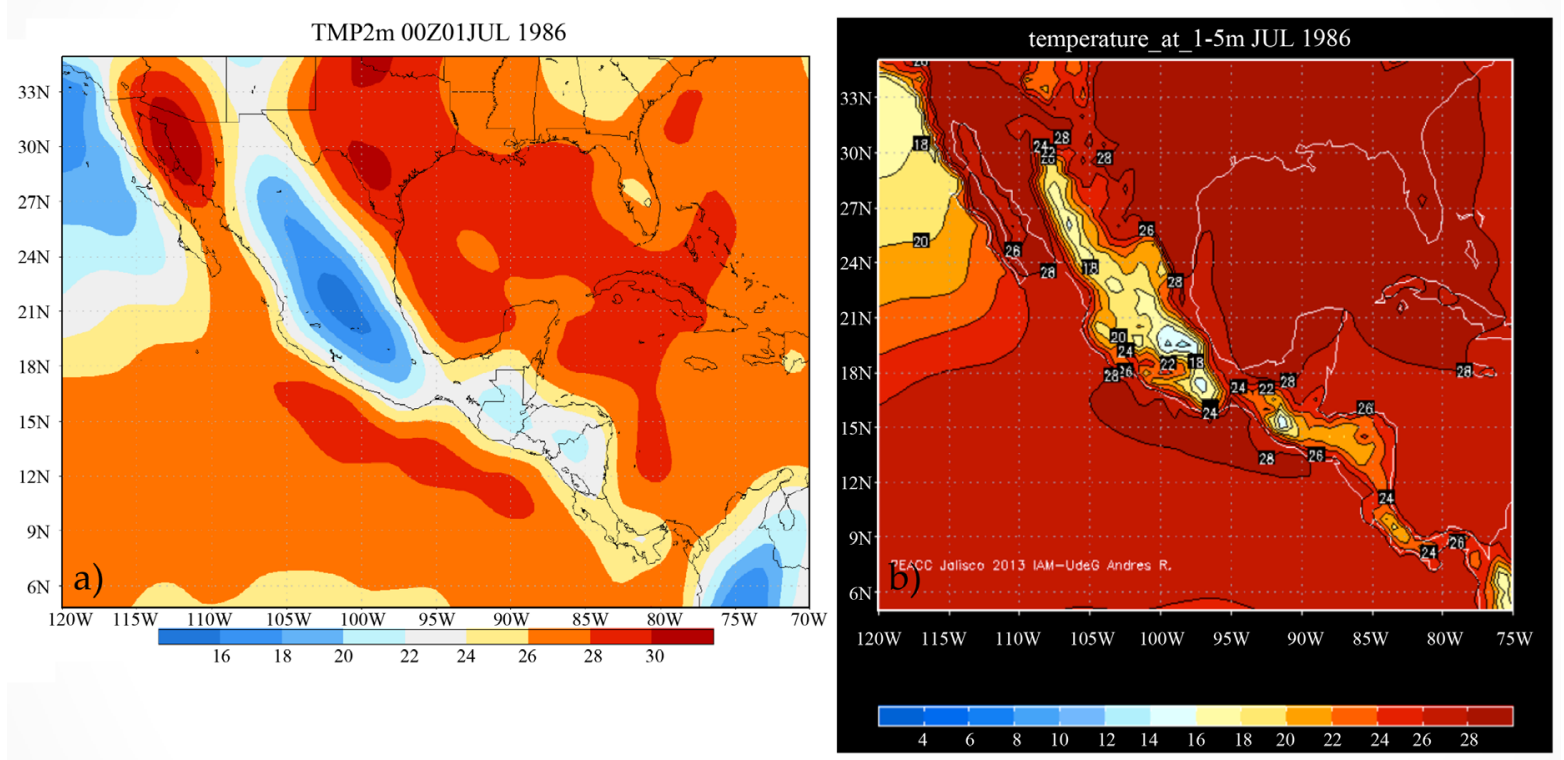

Figure 3. Temperature image for July 1986 of México obtained from (a) NOOA and (b) PRECIS database. 

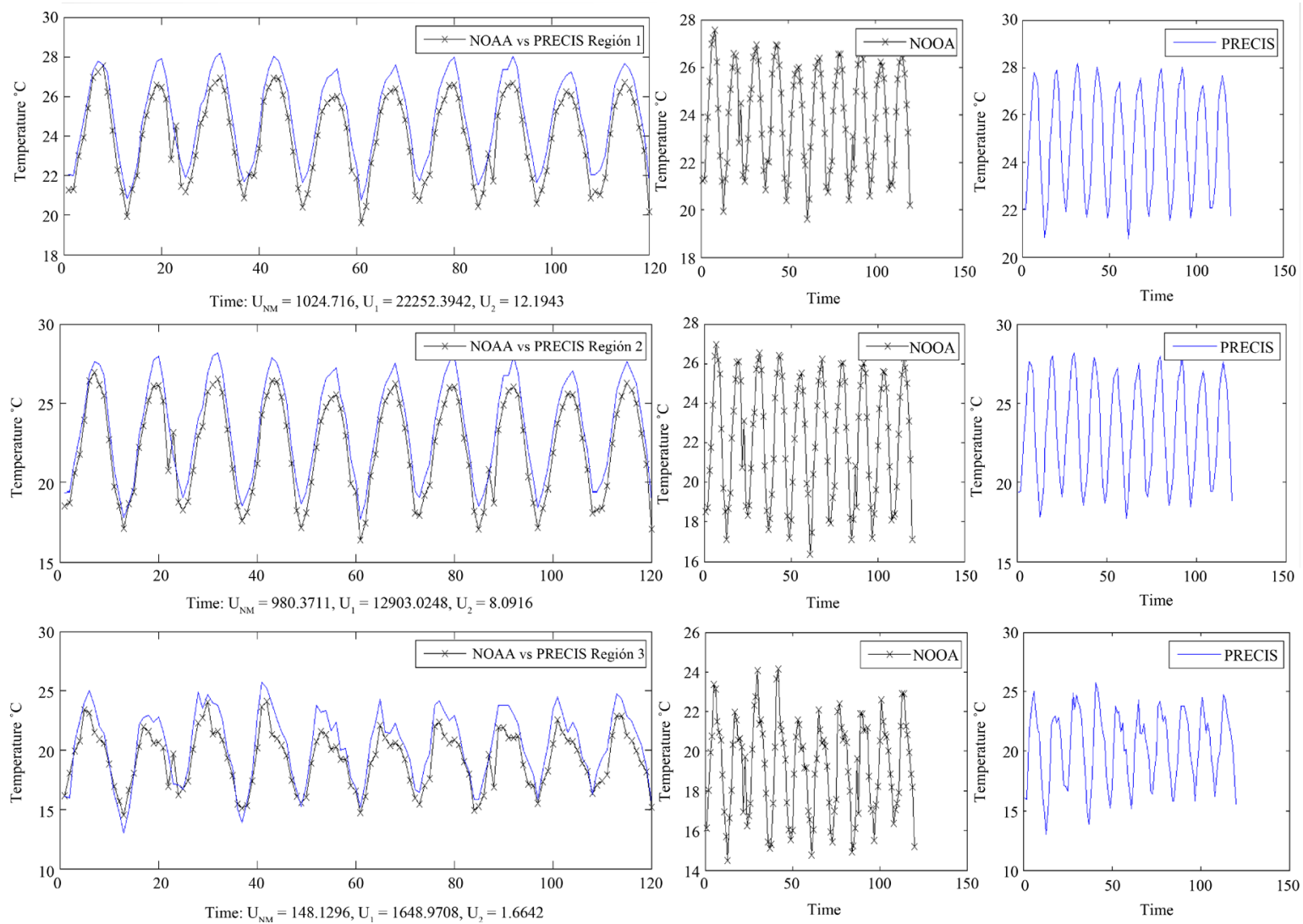

Figure 4. Comparison of temperatures for July 1986 of México obtained from (a) NOOA and (b) PRECIS database.

Ramirez et al. [3] have presented the annual cycle of average air surface temperatures and have shown that the highest temperature during the dry season, followed by the fall during the stormy and winter months, is well represented by PRECIS.

\subsection{PRECIS Scenarios}

Observational analysis suggests notable changes in temperature extremes over Jalisco. Therefore, it is of great interest to focus especially on the daily data to assess likely future changes towards the end of the 21st century. PRECIS-generated daily temperature data are used to predict changes in extreme temperatures in the periods 2020, 2050 and 2080. Ramirez et al. [3] have shown that PRECIS simulations in scenarios of increasing concentrations of greenhouse gases and sulfate aerosols indicate a marked increase in average air temperature in the State of Jalisco at the end of the 21st century. Their analysis also shows that the patterns of temperature change projected under A2 and A1B scenarios are similar, but the scenario A2 shows a lesser magnitude of projected change. Warming is monotonically predicted over the State of Jalisco (Figure 5).

The probability distribution function of the frequency of extreme events, using maximum and minimum daily temperatures observed from 197 stations, were calculated. From these probability distributions, the values of both tails on the extremes of the distribution of frequencies are selected so that $10 \%-15 \%$ observations are kept outside chosen limits. These values are chosen to determine the frequencies of annual heating and cooling. Maximum temperatures of $15^{\circ} \mathrm{C}-35^{\circ} \mathrm{C}$ are the values of the lower and upper tail, respectively. For the minimum temperatures, these values are obviously lower, and approximately $10^{\circ} \mathrm{C}$ and $25^{\circ} \mathrm{C}$ represents the values of the lower and upper tail.

Using these values as thresholds defined by the user, the frequency in terms of the number of days per year are calculated for the number of hot days, cold days, warm nights and cool nights on each baseline grid, for both A1B and A2 scenarios.

For the future scenarios (2020-2100), the frequencies of warm days $\left(\mathrm{Tx}>35^{\circ} \mathrm{C}\right)$ and nights $\left(\mathrm{Tn}>25^{\circ} \mathrm{C}\right)$ are 


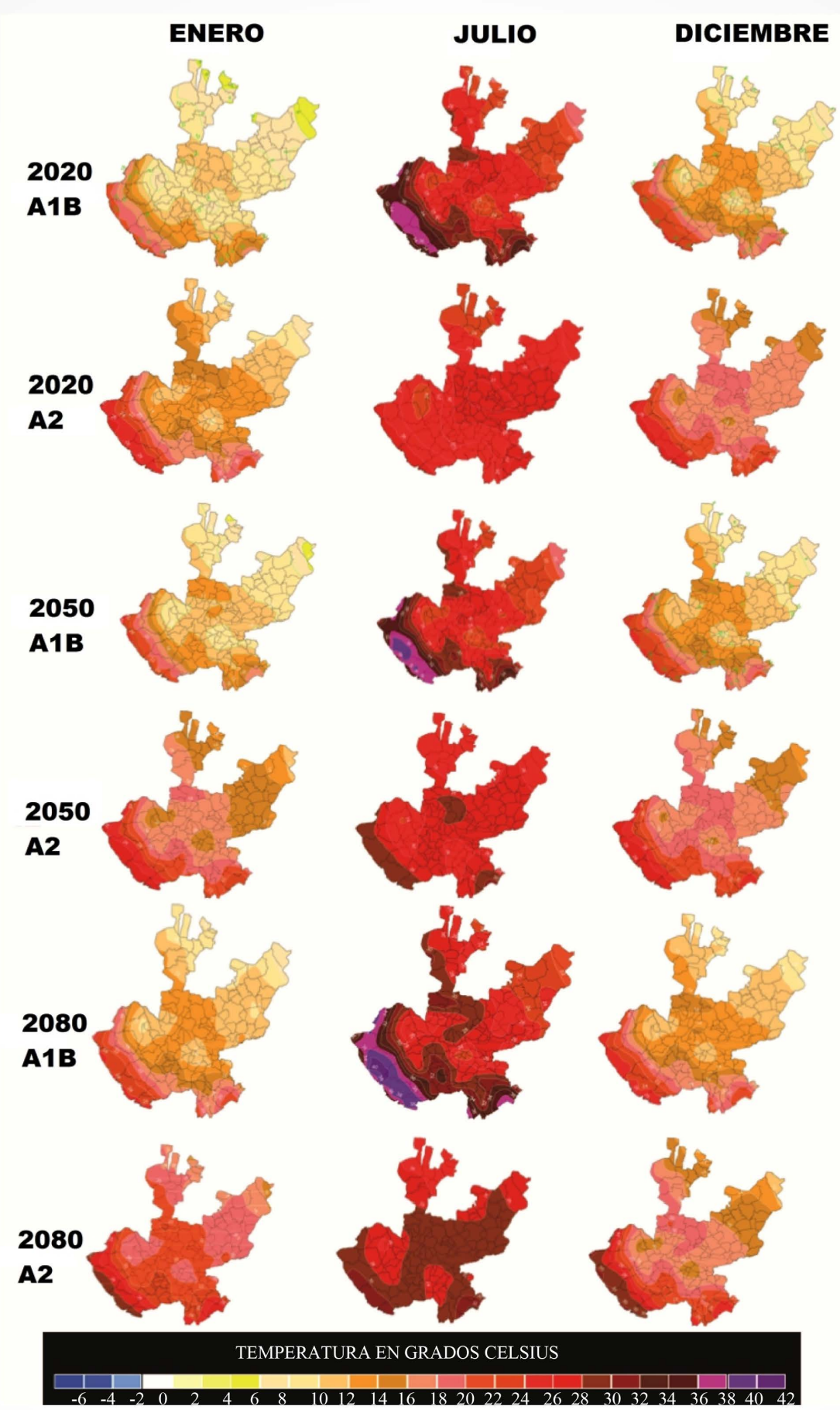

Figure 5. Projected temperature patterns of PRECIS under scenario A1B and A2 is State of Jalisco.

increasing, while the frequencies of the cool days $\left(\mathrm{Tx}<15^{\circ} \mathrm{C}\right)$ and nights $\left(\mathrm{Tn}<10^{\circ} \mathrm{C}\right)$ are declining.

The increase in the warm nights of A2 scenarios with respect to the baseline is $180 \%$, which is the highest in terms of percentage days, while the frequency of cold days shows a lesser decreasing index of $35 \%$. Higher indices are seen in the frequencies related to minimum temperatures than frequencies related to the maximum temperature.

Greater changes are seen through both warm and cold frequencies in the A2 scenarios compared with the A1B 
scenarios. The regression method has been used to correct the bias using indices calculated with the model and the observed data. Correction of bias estimates also show similar results with slightly lower magnitude. Therefore, similar to the observed results, the rate of increase of hot events and decrease of cold events is more notable at night, i.e., minimum extreme temperatures.

Diurnal temperature range (DTR). In the northern hemisphere, it is expected that surface air temperatures rise steadily from January to June and decrease from July to December of each year. In the State of Jalisco, the basic character of the annual cycle of surface temperature follows this behavior. The rainy season is active throughout the region during the months of July to mid-September. Therefore, higher temperatures are experienced usually from April to June, immediately before the storms, and high rainfall is experienced from July to September. Annual cycles in terms of monthly variation for the average of maximum/minimum temperatures and extreme indices of highest maximum temperature and lowest minimum temperature show increase in maximum temperature from March, reaching a value peak in June and gradually decreasing towards December.

The stormy months, due to clouds and a humid climate, show a reduction of the maximum temperatures and increase in minimum temperatures [40] [41]. The annual cycle of the diurnal temperature range (DTR), which is defined as the difference between daily maximum and minimum temperatures, is affected by variation in the annual cycle of maximum and minimum temperature. The minimum temperature is controlled to a large extent by a decrease in long-wave radiation, while the maximum temperature is strongly affected by solar heating of the surface and partially by the sensible and latent heat [42]-[44]. Trends in DTR can be affected by a large scale increase in GHGs and aerosol [45] [46].

The DTR was calculated for the baselines 1971-2000 and 1981-2010, as well as scenarios A1B and A2 (2071-2100). In Table 4, the monthly average values mean DTR for the State of Jalisco for each time interval are shown. The basic characteristics of temperature variation are well reflected with high values of DTR's of $66 \%$ and 71\% increase. The annual cycles of DTR in A1B and A2 scenarios also show similar patterns. However, reduced DTR values contribute 33 and 29 percent of the sample respectively for the studied periods.

\section{Conclusions}

A comprehensive analysis has been carried out in the present study of extreme temperatures observed in the State of Jalisco, using daily representative data of good quality to detect and quantify the climate changes observed in terms of extremes and also to assess the representations of the climate obtained from regional climate models and provide probable future extreme temperature projections based on their simulations of two different socio-economic scenarios (A1B, and A2). Changes in extremes are studied in terms of their frequency, intensity and duration using a standard set of indices defined objectively in a globally standardized framework. The followings are some of the main conclusions based on the results presented in various sections of this document.

Observational analysis based on the daily maximum and minimum temperature for the period 1971-2000 and 1981-2010 using a network of 208 well distributed stations indicated a general warming in the State of Jalisco, both through indices of frequency and of intensity of extreme temperatures. Changes in semiaverages in the annual cycles in terms of extreme monthly temperatures show a warming in every single month. Spatial patterns

Table 4. DTR of the stations in the State of Jalisco in the periods 1971-2000 and 1981-2010.

\begin{tabular}{|c|c|c|}
\hline \multirow[b]{2}{*}{ Changes } & \multicolumn{2}{|c|}{ DTR } \\
\hline & $1971-2000$ & $1981-2010$ \\
\hline Positives & 155 & 109 \\
\hline Negatives & 79 & 44 \\
\hline Total & 234 & 153 \\
\hline Average & 1.26 & 1.27 \\
\hline Standard Deviation & 3.29 & 2.87 \\
\hline Maximum & 15 & 11.02 \\
\hline Minimum & -10 & -13.42 \\
\hline \% Increment & 66.24 & 71.24 \\
\hline \% Diminution & 33.76 & 28.76 \\
\hline
\end{tabular}


indicate marked changes to warming across the State. The highest magnitude changes in extreme temperatures are seen in the spring and summer months more so than in the rest of the year.

The study also presents future scenarios of likely extreme temperatures in the State of Jalisco, deduced from a regional climate modeling system known as PRECIS, for the period 2020-2080. Simulation models suggest a reasonable ability in the representation of the present climate of Jalisco. Simulation models with scenarios of increased concentration of greenhouse gases and sulfate aerosols indicate a marked increase in both temperature maximums and minimums towards the end of the 21st century. Space-time graphics from PRECIS of the daily maximum and minimum temperatures show general projections of a warming of around $3.5^{\circ} \mathrm{C}$ over the whole year towards the end of the 21st century, but the changes in the dry season are more prominent than those in the rest of the year.

PRECIS under both the A2 and A1B scenarios indicates frequency of episodes of extreme heat and also the consequent increase in intensity towards the end of the 21st century. There is a marked decrease in the frequency of cold events obtained by the maximum temperatures, as well as the minimum. Both scenarios A1B and A2 show similar patterns of projected changes in extreme temperatures towards the end of the 21st century. However, the scenario A2 shows lower magnitudes of the projected changes than the scenarios A1B.

So, while the analysis of the observed trends and future projections of the extremes in surface temperature indicate large-scale regional changes through all indices, it is necessary to examine the extremes in detail, both on spatial and temporal scales and also to study the factors affecting the improvement of the extremes. Future scenarios are based on assumptions about the future development of the world. Climate models do not reproduce the weather precisely in a specific place at a specific time. The estimates have uncertainties associated with them, which should be evaluated using more sets of model simulations. Changes in the duration of insolation, wind speed and relative humidity are also important to study future climate change with all the possible intermediate scenarios.

\section{Acknowledgements}

The authors thank to the National Meteorological Service (SMN) belonging to the National Water Commission (CNA), attached to the Ministry of Environment and Natural Resources (SEMARNAT), the Ministry of Environment and Territorial Development (SEMADET) of the State of Jalisco, the State Council of Science and Technology of the State of Jalisco (COECYTJAL) and the National Council of Science and Technology (CONACYT) of the Federal Government for support for the implementation of this project. Also thanks to the Hadley Center of the Met Office of the United Kingdom, who provided available regional models and their data products required for this study.

\section{References}

[1] IPCC (2007) Climate Change 2007: The Physical Science Basis. In: Solomon, S., Qin, D., Manning, M., Chen, Z., Marquis, M., Averyt, K.B., Tignor, M. and Miller, H.L., Eds., Contribution of Working Group I to the Fourth Assessment Report of the Intergovernmental Panel on Climate Change, Cambridge University Press, Cambridge.

[2] IPCC (2014) Cambio climático 2014: Impactos, adaptación y vulnerabilidad—Resumen para responsables de políticas. Contribución del Grupo de trabajo II al Quinto Informe de Evaluación del Grupo Intergubernamental de Expertos sobre el Cambio Climático. Field, C.B., Barros, V.R., Dokken, D.J., Mach, K.J., Mastrandrea, M.D., Bilir, T.E., Chatterjee, M., Ebi, K.L., Estrada, Y.O., Genova, R.C., Girma, B., Kissel, E.S., Levy, A.N., MacCracken, S., Mastrandrea, P.R. and White, L.L., Eds., Organización Meteorológica Mundial Ginebra, Suiza, 34 págs. (en árabe, chino, español, francés, inglés y ruso)

[3] Ramírez-Sánchez, H.U., García-Guadalupe, M.E., Ulloa-Godínez, H.H., Meulenert-Peña, A.R., García-Concepción, F.O. and Alcalá-Gutiérrez, J. (2015) Evaluación de la Vulnerabilidad ante el cambio climático del estado de Jalisco, México. En prensa.

[4] Liu, B., Xu, M., Henderson, M., Ye, Q. and Yiging, L. (2004) Taking China’s Temperature: Daily Range, Warming Trend and Regional Variation, 1955-2000. Journal of Climate, 17, 4453-4462. http://dx.doi.org/10.1175/3230.1

[5] Yue, S. and Hashino, M. (2003) Temperature Trends in Japan: 1900-1996. Theoretical and Applied Climatology, 75, 15-27.

Zhai, P., Sun, A., Ren, F., Liu, X., Gao, B. and Zhang, Q. (1999) Changes in Climate Extremes in China. Climatic Change, 42, 203-218. http://dx.doi.org/10.1023/A:1005428602279

[6] Chung, Y.S. and Yoon, M.B. (2000) Interpretation of Recent Temperature and Precipitation Trends Observed in Korea. Theoretical and Applied Climatology, 67, 171-180. http://dx.doi.org/10.1007/s007040070006 
[7] Kutiel, H. and Maheras, P. (1998) Variations in the Temperature Regime across the Mediterranean during the Last Century and Their Relationship with Circulation Indices. Theoretical and Applied Climatology, 61, 39-53. http://dx.doi.org/10.1007/s007040050050

[8] Hasanean, H.M. (2001) Fluctuations of Surface Temperature in the Eastern Mediterranean. Theoretical and Applied Climatology, 68, 75-87. http://dx.doi.org/10.1007/s007040170055

[9] Beniston, M. and Tol, R.S.J. (1998) Europe. In: Watson, R.T., Zinyowera, M.C. and Moss, R.H., Eds., The Regional Impacts on Climate Change: An Assessment of Vulnerability, Cambridge University Press, Cambridge, 149-185.

[10] Easterling, D.R., Meehl, G.A., Parmesan, C., Changnon, S.A., Karl, T.R. and Mearns, L. (2000) Climate Extremes: Observations, Modelling and Impacts. Science, 289, 2068-2074. http://dx.doi.org/10.1126/science.289.5487.2068

[11] Meehl, G.A., Zwiers, F., Evans, J., Knutson, T.T., Mearns, L. and Whetton, P. (2000) Trends in Extreme Weather and Climate Events: Issues Related to Modeling Extremes in Projections of Future Climate Change. Bulletin of the American Meteorological Society, 81, 427-436. http://dx.doi.org/10.1175/1520-0477(2000)081<0427:TIEWAC>2.3.CO;2

[12] Meehl, G.A., Karl, T., Easterling, D.R., Changnon, S., Pielke, R., Changnon Jr., D., Evans, J., Groisman, P.Y., Knutson, T.R., Knukel, K.E., Mearns, L.O., Parmesan, C., Pulwarty, R., Root, T., Sylves, R.T., Whetton, P. and Zwiers, F. (2000) An Introduction to Trends in Extreme Weather and Climate Events: Observations, Socioeconomic Impacts, Terrestrial Ecological Impacts, and Model Projections. Bulletin of the American Meteorological Society, 81, 413-416. http://dx.doi.org/10.1175/1520-0477(2000)081<0413:AITTIE>2.3.CO;2

[13] Walther, G.R., Post, E., Convey, P., Menzel, A., Parmesan, C., Beebee, T.J.C., Fromentin, J.M., Hoegh Guldberg, O. and Bairlein, F. (2002) Ecological Responses to Recent Climate Change. Nature, 416, 389-395. http://dx.doi.org/10.1038/416389a

[14] Zhai, P., Sun, A., Ren, F., Liu, X., Gao, B. and Zhang, Q. (1999) Changes in Climate Extremes in China. Climatic Change, 42, 203-218. http://dx.doi.org/10.1023/A:1005428602279

[15] Heino, R., Brazdil, R., Forland, E., Tuomenvirta, H., Alexandersson, H., Beniston, M., Pfister, C., Rebetez, M., Rosenhagen, G., Rosner, S. and Wibig, J. (1999) Progress in the Study of Climatic Extremes in Northern and Central Europe. Climatic Change, 42, 151-181. http://dx.doi.org/10.1023/A:1005420400462

[16] Klein Tank, A.M.G. and Konnen, G.P. (2003) Trends in Indices of Daily Temperature and Precipitation Extremes in Europe, 1946-99. Journal of Climate, 15, 3665-3680. http://dx.doi.org/10.1175/1520-0442(2003)016<3665:TIIODT>2.0.CO;2

[17] Plummer, N., Salinger, M.J., Nicholls, N., Suppich, R., Hennessy, K.J., Leigthan, R.M., Treulin, B.C., Page, C.M. and Lough, J.M. (1999) Changes in Climate Extreme over the Australian Region and New Zealand during the Twentieth Century. Climatic Change, 42, 183-202. http://dx.doi.org/10.1023/A:1005472418209

[18] Vincent, L.A., Peterson, T.C., Barros, V.R., Marino, M.B., Rusticucci, M., Carrasco, G., Ramírez, E., Alves, L.M., Ambrizzi, T., Berlato, M.A., Grimm, A.M., Marengo, J.A., Molion, L., Moncunill, D.F., Rebello, E., Anunciacao, Y.M.T., Quintana, J., Santos, J.L., Baez, J., Coronel, G., Gracia, J., Trebejo, I., Bidegain, M., Haylock, M.R. and Karoly, D. (2005) Observed Trends in Indices of Daily Temperature Extremes in South America 1960-2000. Journal of Climate, 18, 5011-5023. http://dx.doi.org/10.1175/JCLI3589.1

[19] Karl, T.R., Knight, R.W., Easterling, D.R. and Quayle, R.G. (1996) Indices of Climate Change for United State. Bulletin of the American Meteorological Society, 77, 279-292. http://dx.doi.org/10.1175/1520-0477(1996)077<0279:IOCCFT>2.0.CO;2

[20] Hyun, S.J., Choi, Y. and Gyu-Holim, J. (2002) Recent Trends in Temperature and Precipitation over South Korea. International Journal of Climatology, 22, 1327-1337. http://dx.doi.org/10.1002/joc.797

[21] Zhang, X., Aguillar, E., Sensoy, S., Melkonyan, H., Tagiyeva, U., Ahmed, N., Kutaladze, N., Rahimzadeh, F., Taghipour, A., Hantosh, T.H., Albert, P., Semawi, M., Karam Ali, M., Said Al-Shabibi, M.H., Al-Oulan, Z., Zatari, T., Al Dean Khelet, I., Hamoud, S., Sagir, R., Demircan, M., Eken, M., Adiguzel, M., Alexander, L., Peterson, T.C. and Wallis, T. (2005) Trends in Middle East Climate Extreme Indices from 1950-2003. Journal of Geophysical Research, 110, D22104. http://dx.doi.org/10.1029/2005jd006181

[22] Alexander, L.V., Zhang, X., Peterson, T.C., Caesar, J., Gleason, B., Klein Tank, A., Haylock, M., Collins, D., Trewin, B., Rahimzadeh, F., Tagipour, A., Ambenje, P., Rupa Kumar, K., Revadekar, J., Griffiths, G., Vincent, L., Stephenson, D., Burn, J., Aguilar, E., Brunet, M., Taylor, M., New, M., Zhai, P., Rusticucci, M. and Vázquez-Aguirre, J.L. (2006) Global Observed Changes in Daily Climate Extremes of Temperature and Precipitation. Journal of Geophysical Research, 111, D05109. http://dx.doi.org/10.1029/2005jd006290

[23] Caeser, J., Alexander, L. and Vose, R. (2006) Large-Scale Changes in Observed Daily Maximum and Minimum Temperatures: Creation and Analysis of a New Gridded Dataset. Journal of Geophysical Research, 111, D05101.

[24] Houghton, J.J., Meiro Filho, L.G., Callander, B.A., Harris, N., Kattenberg, A. and Maskell, K. (Eds.) (1996) The Science of Climate Change. Contribution of Working Group I to the Second Assessment Report of the Intergovernmental Panel on Climate Change. Cambridge University Press, Cambridge, 572 p. 
[25] IPCC (2001) The Scientific Basis. Houghton, J.T., Ding, Y., Griggs, D.J., Noguer, M., Vander Linden, P.J., Dai, X., Maskell, K. and Johnson, C.A., Eds., Contribution of Working Group I to the Third Assessment Report of the Intergovernmental Panel on Climate Change, Cambridge University Press, Cambridge, 881 p.

[26] Mitchell, J.F.B., Karoly, D.J., Hegerl, G.C., Zwiers, F.W., Allen, M.R. and Marengo, J. (2001) Detection of Climate Change and Attribution of Causes. In: Houghton, J.T., Ding, Y., Griggs, D.J., Noguer, M., Vander Linden, P.J., Dai, X., Maskell, K. and Johnson, C.A., Eds., IPCC: Climate Change 2001: The Scientific Basis, Contribution of Working Group I to the Third Assessment Report of the Intergovernmental Panel on Climate Change, Cambridge University Press, Cambridge, 697-738.

[27] Hegerl, G.C., Hasselmann, K., Cubasch, U., Mitchell, J.F.B., Roeckner, E., Voss, R. and Waszkewitz, J. (1997) Multi-Fingerprint Detection and Attribution Analysis of Greenhouse Gas Greenhouse Gas-Plus-Aerosol, and Solar Forced Climate Change. Climate Dynamics, 13, 613-634. http://dx.doi.org/10.1007/s003820050186

[28] Tett, S.F.B., Stott, P.A., Allen, M.R., Ingram, W.J. and Mitchell, J.F.B. (1999) Causes of Twentieth-Century Temperature Change near the Earth's Surface. Nature, 399, 569-572. http://dx.doi.org/10.1038/21164

[29] Stott, P.A., Jones, G.S. and Mitchell, J.F.B. (2003) Do Models Underestimate the Solar Contribution to Recent Climate Change? Journal of Climate, 16, 4079-4093.

[30] Zwiers, F.W. and Zhang, X. (2003) Towards Regional Scale Climate Change Detection. Journal of Climate, 16, 793797. http://dx.doi.org/10.1175/1520-0442(2003)016<0793:TRSCCD>2.0.CO;2

[31] Groisman, P.Y., Karl, T.R., Easterling, D.R., Knight, R.W., Jamason, P.F., Hennessy, K.J., Suppiah, R., Page, C.M., Wibig, J., Fortuniak, K., Razuvaev, V.N., Douglas, A., Forland, E. and Zhai, P.M. (1999) Changes in the Probability of Heavy Precipitation: Important Indicators of Climatic Change. Climatic Change, 42, 243-283. http://dx.doi.org/10.1023/A:1005432803188

[32] Frich, P., Alexander, L.V., Della-Marta, P., Gleason, B., Haylock, M., Klein Tank, A.M.G. and Peterson, T. (2002) Observed Coherent Changes in Climatic Extremes during the Second Half of the Twentieth Century. Climate Research, 19, 193-212. http://dx.doi.org/10.3354/cr019193

[33] Kiktev, D., Sexton, D.M.H., Alexander, L. and Folland, C.K. (2003) Comparison of Modeled and Observed Trends in Indices of Daily Climate Extremes. Journal of Climate, 16, 3560-3571. http://dx.doi.org/10.1175/1520-0442(2003)016<3560:COMAOT>2.0.CO;2

[34] Klein Tank, A.M.G., Peterson, T.C., Quadir, D.A., Dorji, S., Xukai, Z., Hongyu, T., Santhosh, K., Joshi, U.R., Jaswal, A.K., Rupa Kumar, K., Sikder, A., Deshpande, N.R., Revadekar, J.V., Yeleuova, K., Vandasheva, S., Faleyeva, M., Gomboluudev, P., Budhathoki, K.P., Hussain, A., Afzaal, M., Chandrapala, L., Anvar, H., Amanmurad, D., Asanova, V.S., Jones, P.D., New, M.G. and Spektorman, T. (2006) Changes in Daily Temperature and Precipitation Extremes in Central and South Asia. Geophysical Research Letters, 111, D16105. http://dx.doi.org/10.1175/1520-0442(2003)016<3560:COMAOT>2.0.CO;2

[35] Aguilar, E., Peterson, T.C., Obando, P., Frutos, R., Retana, J.A., Solera, M., Soley, J., García, I., González, Araujo, R.M., Santos, A.R., Valle, V.E., Brune, T.M., Aguilar, L., Álvarez, L., Bautista, M., Castañón, C., Herrera, L., Ruano, E., Sinay, J.J., Sánchez, E., Oviedo, G.I., Hernández, O.F., Salgado, J.E., Vázquez, J.L., Baca, M., Gutiérrez, M., Centella, C., Espinosa, J., Martínez, D., Olmedo, B., Espinoza, C.E., Ojeda Núñez, R., Haylock, M., Benavides, H. and Mayorga, R. (2005) Changes in Precipitation and Temperature Extremes in Central America and Northern South America, 1961-2003. Journal of Geophysical Research, 110, D23107. http://dx.doi.org/10.1029/2005jd006119

[36] Kothawale, D.R. and Rupa Kumar, K. (2005) On the Recent Changes in Surface Temperature Trends over India. Geophysical Research Letters, 32, L18714. http://dx.doi.org/10.1029/2005gl023528

[37] IPCC (2000) Informe especial del Grupo de trabajo III del Grupo Intergubernamental de Expertos sobre el Cambio Climático. Nakicenovic, N., Davidson, O., Davis, G., Grübler, A., Kram, T., La Rovere, E.L., Metz, B., Morita, T., Pepper, W., Pitcher, H., Sankovski, A., Shukla, P., Swart, R., Watson, R. and Zhou, D., Gripo intergubernamental sobre cambio climático, OMM, PNUMA.

[38] Jones, R.G., Noguer, M., Hassell, D.C., Hadson, D., Wilson, S.S., Jenkins, G.J. and Mitchell, J.F.B. (2004) Generating High Resolution Climate Change Scenarios Using PRECIS. Met Office Hadley Centre, Exeter.

[39] Sen, P.K. (1968) Estimates of the Regression Coefficient Based on Kendall's Tau. Journal of the American Statistical Association, 63, 1379-1389. http://dx.doi.org/10.1080/01621459.1968.10480934

[40] Revadekar, J.V., Kothawale, D.R. and Rupa Kumar, K. (2009) Role of El Nino/La Nina in Temperature Extremes over India. International Journal of Climatology, 29, 2121-2129. http://dx.doi.org/10.1002/joc.1851

[41] Kothawale, D.R. (2005) Surface and Upper Air-Temperature Variability over India: Its Influence on the Summer Monsoon Rainfall. PhD Thesis, University of Pune, Pune.

[42] Zhou, L., Dickinson, R.E., Dirmeyer, P., Dai, A. and Min, S.-K. (2009) Spatiotemporal Patterns of Changes in Maximum and Minimum Temperatures in Multi-Model Simulations. Geophysical Research Letters, 36, L02702. 
[43] Dai, A., Trenberth, K.E. and Karl, T.R. (1999) Effects of Clouds, Soil Moisture, Precipitation, and Water Vapor on Diurnal Temperature Range. Journal of Climate, 12, 2451-2473.

http://dx.doi.org/10.1175/1520-0442(1999)012<2451:EOCSMP>2.0.CO;2

[44] Makowski, K., Wild, M. and Ohmura, A. (2008) Diurnal Temperature Range over Europe between 1950 and 2005. Atmospheric Chemistry and Physics, 8, 6483-6498. http://dx.doi.org/10.5194/acp-8-6483-2008

[45] Zhou, L., Dickinson, R.E., Tian, Y., Vose, R. and Dai, Y. (2007) Impact of Vegetation Removal and Soil Aridation on Diurnal Temperature Range in a Semiarid Región-Application to the Sahel. Proceedings of the National Academy of Sciences of the United States of America, 104, 17937-17942. http://dx.doi.org/10.1073/pnas.0700290104

[46] Zhou, L., Dai, A., Dai, Y., Vose, R.S., Zou, C.-Z., Tian, Y. and Chen, H. (2009) Spatial Patterns of Diurnal Temperature Range Trends on Precipitation from 1950 to 2004. Climate Dynamics, 32, 429-440.

http://dx.doi.org/10.1007/s00382-008-0387-5 